\title{
Pearl S. Buck and her association with the East
}

\author{
Dr. Dipti Gupta
}

\author{
Anand Engineering College Technical Campus, Agra, India
}

\begin{abstract}
The orient has always been a forbidden fruit for the aesthetic hunger of the western mind. Countless poets, essayists, novelists, philosophers and painters have been charmed and captivated by the exotic east. It has exercised on their imagination a kind of magic spell of the serpent woman.China, being the centre of attraction has always lured people around the world. Apart from Orientalists and Indologists, a long line of creative writers and artists sought their spiritual and aesthetic sustenance from the rich cultural heritage of China.
\end{abstract}

Pearl. S. Buck, an American novelist, has recorded her experiences and views about China in her novels in an excellent manner. She has spent most of her life in China, as she was taken to China at a very young age, by her missionary parents. Since childhood, China became a part of her life, thoughts, and expression. These thoughts found expression in her autobiographical work 'My Several Worlds', and in the two biographies of her father and mother, 'The Fighting Angel' and 'The Exile', and several other novels.The main theme of her novels was Chinese people and their life. She has also seriously digged at the foreign Christians, church and Christianity in her novels. She has dealt the issues like religion, culture, philosophy, man woman relationship, condition of women in China in a fantastic manner in her novels.

My present Paper deals with many of the issues discussed elaborately in the novels of Pearl. S. Buck.

This paper gives a glimpse of China under the rule of Empress Dowager, the defacto ruler of China and one of the most powerful women in Chinese history and her impression on western people, especially on Pearl. S. Buck.

Keywords - China-, People and Life, Feet binding, Man woman relationship, women condition.

Biography - Dr. Dipti Gupta, at present is working as Assistant Professor in Anand Engineering College Technical Campus, Agra, since September, 2007. She has been awarded Ph.D in 2007, in English Literature, from Dr. B.R. Ambedkar University, Agra. She has published a few papers in national and international journals. She is also appointed as Nodal Officer of Spoken Tutorial Project, IIT
Bombay, by Anand Engineering College Technical Campus, Agra

\section{PEARL.S.BUCK AND HER ASSOCIATION WITH THE EAST}

In her autobiographical work Pearl. S. Buck, an American Novelist, had recorded that she had been reared in two worlds- the world of her American parents and captivating China. She was in the curious position of existing in one world and not of it and belonging to another world and yet not of it. Nevertheless she continually attempted to bridge both worlds. She belonged as much to the one as to the other. Her life and her writing had continued to blend the East and the West and she had always managed to see both sides of an issue. So close she has been in mind and heart to the Asiatic scene that after living in the West for twenty four years, it would have been hard for her to declare which side of the world was most her own. She had been loyal to Asia as she had been loyal to her own land. Even though she was an American yet her first home had been China. Emotionally she had been more a Chinese than an American. She had been only three months old when she went to China, with her missionary parents to make her home there. As she grew up, she found herself growing among Chinese and other Oriental people. That she had been an American was impressed upon her by her parents, lest she forget her natural nativity, so immensed she had became in her Chinese environment and living. It was her real world and America seemed to her to be so far away, so unreal, like a dream world, fantastically beautiful with goodness everywhere. But China was the human world, so authentic with pulsating real life. Till a certain age she never considered herself as anything else except Chinese. Less than a year before she had died, she lovingly called China, her other country. What she carried to America after leaving China, was the keen observation of China and its life. She had been greatly impressed by this country, its culture and civilization, which had its impact on other neighbouring Asian countries. She recollects, "When I look back over the twenty years that I have now lived in my own country, I realize that I still do not see my people plain. The years are rich with living but life does not flow here in a river as it did in China"[1]. 
China from its beginning had been ruled

by emperors and empresses and it was used to such kind of political set up. Life here had been a settled, disciplined and traditional one. It is the oldest living nation with a continuous culture, it has the largest population. Once it was the greatest empire in the world and it was a conqueror. It gave the world some of its most important inventions. It has a literature, a philosophy, a wisdom of life, entirely her own; and in the realms of art, it soared where others merely made an effort to flap their wings. It has a sound instinct for life, a strange supernatural, extraordinary vitality. It has led a life of the instinct. It has adjusted itself to

[1.] My Several Worlds, Pearl. S. Buck, Pub by The John Day Company, New York, 1954, Pg 389.

Economic, political and social environments that might have spelled disaster to a

less robust racial constitution. It has a long history of multitude of kings and emperors and sages and poets and scholars and brave mothers and talented women. There are her arts and philosophies, her paintings and her theatres, which provide the common people with all the moral notions of good and evil, and the tremendous mass of folk literature and folklore.

China was a country of high learning and culture, a country having a glorious past, bound inseparably to its rich heritage, drawing life and sustenance from it. Apart from India, it was the only country having such an old and ancient civilization. In other words, it had managed to reach grand old age in the same way as human individuals do, by living much in the open and having a great deal of sunlight and fresh air. But it had also lived through hard times, through recurrent centuries of war and pestilence, and through natural calamities and human misrule. With a grim humour and somewhat coarse nerves, it had weathered them all and somehow it had always righted itself, and this strength, and beauty, culture and civilization, inspired Pearl to record the life of China and Chinese people in her novels like "The Good Earth", "Dragon Seed", "East Wind : West Wind", "The Mother", and such other novels. As Pearl had showed China had been a beautiful, warm, and hospitable country. She remembered China, where there were "wheel barrows, sedan chairs, vendors with their baskets slung on a pole over their shoulders, magicians and street fakirs, wayside shops, women washing clothes at well, and shouting amiably, the neighbourhood gossip, little naked children dashing expertly in and out of the crowded vehicles and legs- it seemed incredible that there could be ways so narrow and people so multitudinous." [2]. Pearl observed that the beauty of China lay in its picturesque past with its accumulated wealth of abundant learning and knowledge, "To me who had always been there it was beautiful inspite of its ancient filth, its illiteracy, its age. Nay, it was beautiful because of its age, and the vast accumulation of its wisdom."[3]. For Pearl had realized that Chinese had been very wise, with their inherited wisdom, a highly refined and cultured race, a refinement which was inborn and inherent in them, "Chinese were born it seemed to me, with an accumulated wisdom, a natural sophistication an intelligent naivette and unless they were transplanted too young, these qualities ripened in them"[4] Even the common men in China, inspite of their illiterate background had been rich in knowledge about life and humanity. Chinese people had been resonable, and ready to change when they understood the need and could easily be persuaded and led, but they were the

[2]. My Several Worlds Pg. 68

[3]. Ibid Pg 243

[4]Ibid Pg. 243

Last people on earth to be forced and this accumulated wisdom is the reason, however that Chinese people were always contended in comparison to the Western people living under the same conditions. This spirit of cheerfulness and contentment is found in both the literate and illiterate classes, for such is the penetration of the Chinese racial tradition.

The training school for developing all virtues, in Chinese character was, however, the big family, where a large number of daughters-in-law, brothers-in-law, fathers and sons daily acquire these virtues by trying to adjust with one another. In the big family, where a closed door was an offense, and where there was very little elbow room for the individuals, one learns by necessity and by parental instruction from early childhood the need for mutual toleration and adjustments in human relationship. From ancient times Chinese families had been united and degnified. Every member of the family was tightly bound with the family by the bonds of love, devotion and sacrifice. For the Chinese, the end of life lies, not in life after death, but in the enjoyment of a simple life. Especially the family life, and in harmonious social relationships. Pearl felt "How long did it take, I wonder for the Chinese people to become so unified, so modeled by history and geography combined through centuries, that their architecture became stylized, a distillation of centuries family living ? It was nothing in my Chinese world to find a family that had lived a thousand years in the same place". [5]. Pearl observed that the families were well ordered, regulated and pulsating with warmth. It was not unusual to find that a family had lived in the same house for generations. "Here his ancestors had 
lived and died and he had been born, the only son of his parents, and here his three sons lived and his grandson"[6]. The family was patterned on joint family system- grand parents, parents, brothers, living under the same roof, sharing the joys and sorrows of life. The family numbered something over sixty persons, including all mouths". [7] .The Chinese roof suggests, therefore, that happiness is first to be found in home. Indeed, the home stands for them as a symbol of peace and security. Every family of the same generation lived in one story rooms, but were united by courtyards to the other generations. "Thus the Chinese realized

the need of the human individual to be alone and yet close to others, especially of his own kind". [8]. In this way, children grew in free security, surrounded by loving adults of various generations, and thus adults shared the burden of family responsibility. No person felt worried on losing his job, because in such

[5.] My Several Worlds Pg 174

[6.] Pavilion of Women Pg-6

[7.] Pavilion of Women, Pearl. S. Buck, Pocket Book edition, 1968 Pg-109

\section{[8.] Pavilion of Women Pg-44}

circumstances the family takes the responsibility of his and his family until a new job was find "Some of the remoter cousins, it is true, had settled in other cities as merchants or in the banks and trade but even these, if they were temporily out of work, came back to the land for a while to recover themselves". [9]. Proper welcome was given to them and proper care taken and they could recoup their loses in an atmosphere of ease, love and harmony. "They were only old cousins and poor nephews who having no shelter elsewhere, had returned to the ancestrol house, to find a corner here and a bed there".[10] There has been no need of orphanages because the family looked after the child. "And the old were loved and revered and never put away into institutions as sometimes they are put away here, and must be put away, I am told because of small flimsy houses where there is only room for two people and their two children".[11]. The family takes the responsibility for the care of the child who had lost his parents. There had been no need of insane asylums, for the family cared for its insane. And in fact there were very few insane for the family provided individual security without disgrace and thus removed one of the main causes for modern insanity, i.e. the lost individual. Even there had been no need of Police, as Pearl records, "In the world of our hills and valleys, and even in the city we needed no Police.

[9]. Ibid. Pg. 43

[10.] Ibid. Pg. 236-237
[11]. My Several Worlds Pg. 44

Each family maintained firm discipline over every member of the group, and if a crime was committed, the family elders sat in conference and decided the punishment, which sometimes was even death". [12]

Chinese families had been disciplined and quite capable of self-government. They had a traditional family system in which every individual man, woman and child belonged to a clan and each clan had been responsible for all individuals in it. There had been no need of relief rolls for again the family cared for its members who had been jobless. It had been only in the times of widespread famine and catastrophe, need of outside help, and then even the family stayed together "Business was stable in a large middle class, for the generations carried it on in the same family. Nepotism, it is true, tended to be a problem, since it was natural that a man would try to get jobs for his relatives. Yet I do not see the difference between family nepotism in China and political nepotism in the United States, and of the two, family nepotism in China seems the less dangerous to society because the family still remained morally responsible for each of its members, and the disgrace of any member was a family disgrace". [13].

The Chinese believed that they owed a lot to their ancestors. They considered themselves merely a link in the long chain of generation, past and on coming. Their body was a legacy to them by their parents and hence repayment in some form had to be made. They owed duty to them foremost above everyone else.

[12.] My Several Worlds Pg. 13

[13.] .Ibid Pg. 123

The body was their gift to them and had to be rendered unto them only. "I know that I am made, not only by heaven, but also by my family whose roots are in legend, and I cannot live for myself alone. My body was given to me, it does not belong to me. Something in me is my own, that is true, and that something - call it soul, if you wish - is my own possession and I can give it to you because I love you. But if I were to give my body, which is not mine, I should be robbing the generations". [14]. Chinese were wise enough to realize that content overrode all feelings, and content came when duty was done and expectations fullfilled, "not the personal expectations of love, but the expectations of family and children, home and one's place in the generations."[15].

If the family system in China had been united and strong, it was because China had been a country, where human relationships were the first concern. The lines of relationship were well defined and every one knew what his position was in the family and what his code of conduct 
ought to be. For the reputation of the family the young were taught how to behave, and though they were treated with much leniency until they were seven or eight years old, and after passing this age they use to learn to respect the code of human relationships that is set forth by Confucius, but before the age of seven or eight years the Chinese children had been alarmingly spoiled, because the Chinese had a different view on

[14.] Pavilion of Women Pg. 308

[15.] Ibid Pg. 308

Discipline, "Discipline in their estimation, was the expression of adult anger and the child must as a matter of course be protected, since anger was merely a sort of dangerous seizure." [16]. And this is the reason, children in China were, till a certain age, badly indulged and spoiled by their parents, grand parents, closer and lesser relatives, servants and amahs, and all their big and small wishes and whims were fulfilled. "Everyone else in the family was still sleeping except the grand children, whom the amahs would be amusing in some corner of the vast compound until the parents awoke." [17]. Full attention was given to the child, especially if he was a son, by his mother and nurse both, for women belonging to rich families did not feed their children themselves, but hired wet nurses from poor families who left their own new born child, to feed the child of the rich family. In this way, the child was pampered by two women, who rejoiced in him." Both young women mother and nurse, adored this little boy all day long. At night he slept in the nurses arms. In this common adoration the two woman found a deep companionship. They poured out, in happy sacrifice, the love and attention, the child demanded." [18]. No one could stop the tantrums or

[16.] My Several Worlds Pg. 10

[17.] Pavilion of women Pg. 6

[18.] Ibid Pg. 18

Willfulness, and a baby was at once picked up, when he cried, and was showed love. No restriction was placed on them, and their habits. They did what they wished, ate what they pleased and when they pleased. The children were not at all allowed to remain hungry, for "it had seemed to her that when a child cried a mother ought to still it somehow and give it ease"[19]. The Chinese believed that a child should not suppress himself, his temper, his spirit for otherwise it would poison his blood and create trouble for him in adult life. "The Chinese believed that it was important to allow a child to cry his fill and vent all his tempers and humors, while he was small, for if these were restrained and suppressed by force or fright, then anger entered into the blood, and poisoned the heart, and would surely come forth later to make adult trouble." [20]. This knowledge was as ancient as a thousand years and still something of this same philosophy is now considered the most modern in the Western world. In this way it can be said that little children in China led a heavenly life. But it is not so, that these children remained spoiled forever. The main aim of this leniency in the childhood was that when these children grew up, they used to become very reasonable and selfdisciplined, able to mould themselves, according to the

[19.] The Mother, Pearl.S.Buck. Pub by Pan Books, 1973, Pg.8

[20]. My Several Worlds Pg. 14

Accepted norms and standards of society. "Right or wrong, these spoiled children emerged like butterflies from cocoons at about the age of seven or eight, amazingly adult and sweet tempered and self disciplined. They were able by then to hear to reason and to guide themselves in the accepted ways. Since they had not been disciplined too soon, when they reached the age of learning they progressed with great rapidity". [21]. The old Chinese believed that there is a certain age for learning each law of life and to teach a child too young was simply to wear out the teacher and frustrate the child. The mind of the child was not as mature and well developed as the mind of an adult person and therefore knowledge, learning basic rules of life had to be imparted gradually, so that they could be easily grasped and received in his mind, without too much strain and unnecessary exertion on his part. Pearl felt that China "was a delightful and lenient world in which a child could live his own life, with many people to love him tolerantly and demand nothing. Instead of the hard pressed father and mother of the Western child, the children of my early world had grandparents, innumerable aunts, uncles and cousins and servants to love them and indulge them" [22].

But Pearl observed that there is a remarkable difference in the upbringing of boys and girls. In the Chinese society girls and boys grew up

[21.] My Several Worlds Pg. 14

[22.] Ibid, Pg. 14

Together in childhood. They played, moved and roamed together, each other's companions and playmates, sharing life and laughter, unconscious of the man made distinctions between them. "As little children we were even together and he it was, who first taught me to brush the ink over the characters outlined in my primer." [23]. But finally this interlude came to an end. As soon as they stepped into adolescene, they were separated. They became conscious of their dissimilarities. "But he was a boy and I only a girl" [24]. A girl child was prepared from the beginning for her role and it was set deeply into her mind that she was inferior to boys. At a very early age boys were shifted to the male 
quarters. "I, of course, was never allowed in the courts where the men lived".[25] Brothers and sisters were not allowed to meet often, and there was rarely any contact even between brothers and sisters. "And when he was nine and I six years of age, he was taken out of the women's apartments into those where my father lived." [26]. The age old conventions bound them, any meeting between them was embarrassing and disconcerting, for both the persons involved. And also it was frowned upon by the elders. "We seldom met then, for as he grew older, he considered it shameful to visit among the women and moreover, my mother did

[23.] East Wind : West Wind, Pearl.S.Buck., Pub. by Pan Books in $1961 \mathrm{Pg}-11$

[24.] East Wind: West Wind Pg.11

[25.] Ibid Pg. 12

[26.] Ibid Pg. 11

Not encourage it".[27]. The consciousness of their sex and status brought about a different attitude and a changed approach towards each other. Pearl observes "They play about promiscuously in the grime, until in a few miraculously short years, the boy turns out in long gowns, and the girls in embroidered coats, with smooth black bands of hair about demure faces. They have apparently forgotten their play time together, and ignore each other with the most perfect good breeding. The little girls go into seclusion with apparent docility, until such time as the great red bridal chair shall call them forth to the rule of a mother-in-law, and the boys turn to school or an apprenticeship, depending upon the family means and social position." [28]. Once secluded from each other the boys rarely entered the women apartments and girls were sternly prohibited. The men's apartments were the haunts of licentious enjoyments and libertinage. Girls of impressionable age were not permitted within those premises for fear of being corrupted in mind and body.

This line of demarcation in the status between men and women prevailed to a certain degree in all sections of society but the code of conduct was more rigid and rigorous in the upper strata of society. The common man was more yielding and easy- going in his relationship but in the aristocratic families much stress was put on right relationship between the sexes. Decorum

[27] Ibid Pg. 19

[28] My Several Worlds Pg. 164

Was the key word in families of rank. "This rigorousness of family decorum was of course not to be found except in the oldest, richest and most conservative families. Among the poorer people and certainly among those who were more modern, there was much freedom." [29].
The Oriental society had mostly been patriarchal, China being the most civilized among them, had also adopted the same social system. The pre-revolution China had not yet felt the impact of the West's liberated communication between the sexes. China was still feudal in its concepts, traditions and norms. It was a society in which it had been laid down since early times that women was subordinate to men, and not equal, " 'Equal with him' " ? She said mystified, her eyes growing large in her pale face. 'What does he mean ? How can you be equal with your husband ?" [30] Women had no freedom to go and come freely. They were reserved and bounded within the four walls of house. "Women who came and went freely like men, I did not consider them".[31] Women were supposed to be reserved, demure. They revealed nothing. They were taught submission and seclusion, and every common or important decision was taken by male members of the family. "The matter was too great for her. It must be decided by our father and by the male heads of the clan."[32] and being reserved and secluded was all the most important in the

[29.] Dragon Seed Pg. 232

[30.] East Wind West Wind Pg. 41

[31.] Ibid Pg. 1

[32.] Ibid Pg. 126

Case of daughters -in-law, as 'Kwei-lan's mother says about her daughter-in-law- "She must learn the seclusion proper to ladies if she is to live here". [33]. A woman after marriage belonged only to her husband's family and no longer to her own and she had to please her husband whether she liked him or not. If she was unable to please

him or claimed by him, then it was considered a matter of worry or shame. "At least no one should know that I had not pleased my husband". [34] So all the ways of a woman ended at her husband's door step. After her marriage, she no longer remained of her own family, and all her concerns, thinking and actions were for her husband's family. This is verified by the statement of Kwei-Lan's mother, when she says to her-" 'Nevertheless, my child, there is only one path in this world for a woman, only one path to follow at all costs. She must please her husband. It is more than I can bear that all my care for you must be undone. But you no longer belong to my family, you are your husband's. There is no choice left you save to be what he desires.' "[35] Women remained in separate courts and did not come in men's presence. It was considered good manners, if

[33.] East Wind Pg. 132

[34.] East Wind : West Wind Pg 23

[35.] Ibid. Pg 42 
Women remained behind men. "They walked home, then she half a dozen paces behind him as befitted a woman."[36] In this way woman were considered as a thing of home. The main work of a man was either to till the ground or look after the family business and of a woman to spin, weave and look after the family and home.

Whereas Pearl had felt relieved to see the united family system in China and happy and secured condition of children in China, she felt greatly pained after observing the condition of women, in Chinese society. Women were regarded as inferior as animals. They were harrassed, tortured and even beaten cruelly and were supposed to bear everything quietly. "Her husband had beaten her twice in her youth, once in anger and once in jealousy."[37]. A marriage was considered successful, if a man could beat his wife and dominate her in any way. It was said, "The best marriage was where the man could beat the woman, and she was proud of her son." [38] and if a man could beat his woman it was considered by him as a thing to be proud of and become happy. " but I swear that if I were you, I would beat that woman until she leaned against the wall to keep from falling."[39] Though women were of common sense and practical

[36]. The Good Earth, Pearl.S. Buck, Pub by Pocket books, New-york, January 1970, Pg. 17.

[37.] Dragon seed, Pearl.S.Buck, Pub by The John Day Co. New York, 1942, Pg. 12

[38.] Ibid Pg. 24

[39.] Ibid pg. 232

mind, still the conditions and inferior position of women in Chinese society forced them to commit suicides and this was the reason, "Suicides among young women were not uncommon." [40]. The only place for them was family and home and all the world was for men. "From the moment she had been born even in Ling Tan's house she had known that walls are closed around a woman but the gate is open to a man." [41]. Her relationship with her own family became secondary for her, and primary was her concern and consideration for her husband's family.

The thing that Pearl found very painful and irritating in China, was the custom of feet binding. The Chinese believed that the beauty of a woman lay in her tiny feet. To accomplish it, feet were rigorously bound from the young age only, however painful the process was, for the child. The binding of feet, if done properly was started when the girl was five or six years old. The feet were bound by yards of cloth that would not stretch. To start the process, the foot was extended at the ankle, and the fleshy part of the heel was pushed down and forward under the foot. The foot was then carefully bound up with the material. The tight binding primarily cut the circulation, and retarded the growth of the foot. It was easy to see that the toes would become bent under the pressure and would not spread out to the normal width. The binding would force the foot to

[40.] My Several Worlds Pg. 150

[41.] Dragon Seed pg. 312

become narrow and tapering. After a while, the toes would stay curled under, even when the bandages were removed for cleaning and changing. All this pain was given to girls for the sake of small feet. "In that world it was important to be a woman and if possible a beautiful woman, and small feet were a beauty that any woman could have, whatever her face."[42] In this process, often the skin and flesh broke and cracked if too much pressure was applied or if the feet of an older girl were bound. If sores appeared, they were difficult to heal. The bandages had to remain on if the process was to work because of the necessity of constant pressure. That is why there is an old Chinese saying. For every pair of small feet, there is a jar full of tears. Many sleepless nights girls had to spend because of pain and suffering. "Because my mother binds a cloth about my feet more tightly everyday and I can not sleep at night."[43] Small feet were considered necessary for every girl for getting good husband also" I am glad for every girl who does not have her feet bound, for I spent my nights in weeping, when I was a girl, before my feet grew numb, yet if she is not bound footed she must be educated, otherwise she will not get a husband. A small footed girl can get an old fashioned husband, and a big footed girl, if educated ,can get a new fashioned husband, but small feet or schooling, she must have one or the other."

[42.] My Several Worlds Pg. 12-13

[43.] The Good Earth Pg. 180

[44.] My Several Worlds Pg. 47

Even at night women used to hide their feet from the sight of men, "We chinese women never expose our feet to the sight of others. Even at night we wear stockings of white cloth." [45] This painful and unnatural process added one more trouble in the life of women in China. It was not easy to abolish it,for it had became a part of Chinese culture.

The man woman relationship in China was marked by a great demarcation and this demarcation was apparent since the time of birth only. The birth of a baby boy was celebrated with gaities, pomp and ostentatious show. It was an sp. occasion of joy and hope. The son kept alive the name of the family and it was considered a duty of a woman to bear sons for the family. If a daughter-in-law was unable to bear a son then she was considered imperfect." I cannot 
see how even your mother-in-law will find anything lacking in my work, unless you should bear no son." [46]

The heritage of a family should keep on passing from one generation to another and a son was the link that joined the generations together for continuity of the heritage, "He stood in their midst, the center of them all..... He was a symbol of continuing life. It was the symbol which held all their dreams"[47] Even liberated

[45.] East Wind West Wind Pg.33

[46.] East Wind West Wind Pg. 6

[47.] Pavilion of Women Pg. 19

And emanicipated Mr. Liang could not forgo completely the traditional concept and the desire for a son finally touched some chord in the recesses of his heart and because of it the second lady was welcomed in the house against the wishes of Madame Liang. "yet it was a last quarrel, for the woman outside did give him a son, and suddenly all Chinese, he brought her into his house as his concubine, so that the child had his name and a place in the family a higher place than that of her daughters. Was he not male."[48] But the birth of a girl was an ominous sign, portending evil for the house. They were of no use for the family and from their birth only, were considered a drain on their father's pocket. They were called slaves and no right was given to them. Any evil happening in the family was thought to have been brought by girls only. "A sense of evil struck him. A girl, A girl was causing all this trouble in his uncle's house. Now a girl had been into his house as well"[49] In a family where there were too many girls, orders were given to the midwife to strangle the child after perceiving her to be a girl soon after the birth. Such a cruel custom! Belonging to such warm, intensely emotional people, welcoming even strangers amidst themselves, with so much real affection and yet discarding their own vital and living part and nullifying it. Girls were considered "Worthless, oldest slave creature."[50] Pearl Buck herself

[48.] The Three Daughters of Madame Liang, Pearl. S. Buck, Pocket

$$
\text { Book Edition, 1971, Pg. } 7
$$

[49.] The Good Earth Pg. 46

[50] Ibid Pg. 43

Was moved by the sad woeful tales of bereaved mothers. But all was not cruelty in their nature and "daughters when they lived were tenderly loved and death had to be done at birth or it was not done at all." [51] But it was a cruel system nevertheless, and instances of this injustice are scattered in several of Pearl's books. O-Lan in, 'The Good Earth' kills the baby girl at the time of her birth, only because money was short and also daughters did not carry the family name. "Daughters do not belong to their parents but are born and reared for other families."[52]Their indignity was more pronounced when they were sold by their parents as common slaves, for handful of grain during the times of famine. This fate was not for the sons of the family, however dire the circumstances. O-Lan was herself a slave in the 'House of Hwang' "This woman came into our house when she was a child of ten and here she lived until now, when she is twenty years old. I bought her in a year of famine when her parents came south, because they had nothing to eat............... So far as I know she is virgin. She has not beauty enough to tempt my son and grand sons, even if she had not been in the kitchen. take her and use her well" [53]

The fate of these slaves, if they happened to be pretty was all the more worse, for being dependent, and with an insignificant status in the family,

[51.] My Several Worlds Pg. 146

[52.]The Good Earth Pg. 46

[53.] Ibid. Pg. 13

They became tools for the satisfaction of the carnal desires of the men of the house. "Moreover who has heard of a pretty slave who was virgin in a wealthy house? All the young lords have had their fill of her."[54] Even the old lords of

aristocratic, rich families used them as objects for fulfilling their lust- "And as if this were not enough, the old lord took yet another concubine, a slave, who was the child of a slave, who had been his creature in her youth, but who was now wed to a man servant in the house, because the old lord's desire for her failed, before he took her into his room as concubine. This child of the slave, who was not more than sixteen, he now saw with fresh lust, for as he grew old and infirm and heavy with flesh, he seemed to desire more and more women who were slight and young even to childhood, so that there was no slaking his lust."[55] The slave girls got a very inhuman treatment. They were beaten, raped and even killed in rich houses. Just like animals they were beaten for without any reason or for insignificant reason, "I was beaten with a leather throng which had been halter for one of the mules and it hung upon the kitchen wall."[56]They were treated as machines, for the household work, and for satisfying the lust of men in the house. Not a single night they slept soundly for daily they were raped

[54.] The Good Earth Pg. 6

[55]. Ibid Pg. 48

[56.] Ibid Pg. 96

"Aye, beaten or carried to a man's bed, as the whim was, and not to one man's only but to any that might desire her 
that night, and the young lords bickered and bartered with each other for this slave or that" [57] This heinous act was dealt by Pearl most skillfully and truthfully in her famous novel 'The Good Earth' where O-Lan was herself a slave and had experienced and seen all with her own eyes.

The Chinese male by nature, was permissive. The result of his permissiveness was the concubine system, which was deeply established in the Chinese way of living. Men were allowed their wandering moments. Their amorous dealings, with women other than their wife were accepted by the society, and not looked down upon or slandered. A man was a superior being, and so had a right to keep as many women as he wanted. These second or third women, whatever be the number, were known as concubines. They were an eternal threat to the legitimate wife. "A concubine is brought into her lover's house and family. Of course this is an annoyance to the wife unless she despises her husband, in which case she is glad to be relieved of her wifely duties."[58] Wife, in customary Chinese family was not needed to be pretty. A women was a house wife first and if happened to be pretty, she would not only distract her husband from his duties, but would also be petulant and constantly exploit her

[57.] The Good Earth Pg. 96

[58.] The Three Daughters of Madame Liang, Pg. 18

Husband's weakness for her. Beauty was not much appreciated, in the farm folks, where life was hard and necessitated the harmonious working of men and women together. This was the obvious remark of an average farmer, "And what will we do with a pretty woman?. We must have a woman who will tend the house and bear children as she works in the fields, and will a pretty woman do these things ? She will be forever thinking about clothes to go with her face ; no, not a pretty woman in our house."[59]. As a matter of fact, in north China woman purposely remained unkempt, unpolished, uncombed so as to escape comparison with the prostitutes with their clean, smooth and tidy appearance. There was no distinction between the rich and the poor, for a rich lady would wear her satin coat underneath a faded blue cotton one. "Honest women took pride in being unkempt as a sign of not caring how they appeared to men and therefore virtuous."[60]. These women, harrassed with tending the house, bearing the children, working in the fields, soon lost the freshness of youth ; the charm and appeal which youth had bestowed to them swept past them as a whiff of fragrance. They became jaded and faded too soon, and men who had slaked their desires with them, begeting sons through them, soon perceived this change, and with their roving instinct, soon became irresistably drawn to some other woman, youthful in face and body, who had happened to catch their fancy.

[59.] The Good Earth pg.6

[60.] My Several Worlds pg.135

Men who frequented often the Flower house, would generally come across pretty girls, rouged and powdered, out to entrap these men, and men like gullible fools, unknowingly would be enmeshed in some pretty face, unfeeling towards their drab wives, already having sucked the best of their youth. O-Lan, the faithful wife of Wang lung, who had given so much to her husband-love, sincerity, hard labour, sons, and her youth, was finally faced with this heart rending realization. "And it is not to be thought poor fool, that one woman is enough for any man, and if it is a weary hard working woman who has worn away her flesh working for him, it is less than enough for him. His fancy runs elsewhere the more quickly, and you poor fool, have never been fit for a man's fancy and little better than an ox for his labour. And it is not for you to repine when he has money and buys himself another to bring her to his house." [61]. Money, indeed played an essential part, for it was only a well to do man, who could afford women other to his wife. Then expensive gifts had to be presented and monetary transaction made with the guardians. "So have all men who have prospered. It is only the poor man who must needs drink from one cup." [62]. Proper negotiations would then be made and middle man appointed for them. The second wife would then come properly to her lover's house and lead a life of ease, and would be much pampered, whereas the first wife had to continue her ardous tasks of house

[61.] The Good Earth Pg. 137

[62.] Ibid pg. 138

Keeping. Lotus, the concubine of Wang Lung," never came forth in the heat of early autumn days, but she lay while the woman Cuckoo bathed her slender body with lukewarm water and rubbed oil into her flesh and perfume and oil into her hair. All day the girl lay in the cool darkness of her room, nibbling sweet meats and fruits."[63]. This inevitable bitter catastrophe of life had to be swallowed, but some times the repercussions were severe for, "Some women will even hang themselves upon a beam with a rope, when a man takes a second woman into the house, and others will scold and contrive to make his life worthless for what he has done".[64]. The reaction was different, differing from individual to individual. O-Lan maintained a sullen silence ; Kwei-Lan's mother, the first lady of the house remained indifferent and unresponsive, going on her way in her usual dignified and graceful manner, but Madame Liang was different. Unrestricted and unrestrained by her father, 
studied in Paris, married for love to the partner directly chosen by her, an avid follower of Sun-Yat-sen, and an active participant in the revolution invoked by this great Chinese leader, she could not remain docile and dormant, and did not welcome meekly when her husband brought home another woman. She had left him outrightly, "At least she had determined her own fate and at least she had not accepted his blame while he brought other woman into the house."[65] It was very rare indeed, when

[63.] The Good Earth pg. 143-144

[64.] Ibid pg. 145

[65.] The Three Daughters of Madame Liang pg.6

Woman herself offered and arranged for a concubine for her husband, for she wanted to be relieved of her wifely duties. Madame $\mathrm{Wu}$, was one of those sort. Her own fires were dead, whereas her husband's burned with the same intensity. Besides, she had never been a very sensual woman. Her intellectual, aesthetic mind now craved satisfaction, for this hunger for knowledge which had lain torpid in her for so long, and hence her proposition to her husband so that even he might not be neglected, and so that someone might take her place in fulfilling the wifely duties towards her husband. Madame Wu confides to her mother-in-law, "Yesterday I was forty years old. I had long made up my mind that when that day come I would retire from my duties as female and find someone for my lord, who is young. He is only forty five years old. He has many years left him yet."[66]. Besides there was the law of nature. Woman's fertility faded too soon, whereas a man's need to plant his seed continued for long to be fulfilled through one woman. And could the decree of heaven be changed, "Heaven valuing only life, had given seed to man and earth to woman. Of earth there was plenty but of what use was earth without seed? The truth was that a man's seed went on even after his bones were chalk and his blood water, and this was because the Heaven put the bearing of children above all else lest mankind die. Therefore must the very last seed in a man's loin be planted, and that this last seed might

[66.] Pavilion of Women Pg. 40

Bear strong fruit, as the man grew old, the seed must be planted in better and

stronger soil. For any woman, therefore, to cling to a man beyond the time of her fertility was to defy Heaven's decree. "[67].

Pearl's reminiscences of her beloved China are scattered all over the pages of her various books. Her books are the living documents of her life in China, her impressions of Chinese life, men and women, their culture , their customs and the warm affection which she received from them. One who wants to gain profound knowledge on Chinese history, culture, politics, peasants' condition and family life needs to have a study of her novels.

[67.] Pavilion of Women Pg. 36

\section{REFERENCES}

[1] My Several Worlds, Pearl. S. Buck, Pub by The John Day Company, New York, 1954.

[2] Dragon Seed, Pearl.S.Buck, Pub by The John Day Co. New York in 1941

[3] For Spacious Skies: Journey in Dialogue, Pearl. S. Buck, Printed in 1966 by the John Day Company Newyork.

[4] Letter from Peking, Pearl.S.Buck, This Best seller Book club edition is published by special arrangement with the John Day Company in 1957.

[5] Pavilion of Women, Pearl. S. Buck, Pocket Book edition, 1968.

[6] Three Daughters of Madame Liang, Pearl. S. Buck, Pocket Book Edition 1971

[7] The Mother, Pearl.S.Buck. Pub by Pan Books, 1973

[8] East Wind : West Wind, Pearl.S.Buck., Pub by Pan Books in 1961

[9] The Good Earth, Pearl.S. Buck, Pub by Pocket books, New-york, January 1970. 